\title{
GCU
}

Glasgow Caledonian

University

University for the Common Good

\section{Heat recovery from mineworkings: opportunities in the Glasgow area}

Hytiris, Nicholas; Emmanuel, Rohinton; Aaen, Bjorn; Church, Emma Suzanne; Campbell, Diarmad Seumas; Ninikas, Konstantinos; Robertson, Andrew

Published in:

Environmental Geotechnics

DOI:

10.1680/envgeo.15.00007

Publication date:

2017

Document Version

Author accepted manuscript

Link to publication in ResearchOnline

Citation for published version (Harvard):

Hytiris, N, Emmanuel, R, Aaen, B, Church, ES, Campbell, DS, Ninikas, K \& Robertson, A 2017, 'Heat recovery from mineworkings: opportunities in the Glasgow area', Environmental Geotechnics, vol. 4, no. 6, pp. 395-401. https://doi.org/10.1680/envgeo.15.00007

\section{General rights}

Copyright and moral rights for the publications made accessible in the public portal are retained by the authors and/or other copyright owners and it is a condition of accessing publications that users recognise and abide by the legal requirements associated with these rights.

Take down policy

If you believe that this document breaches copyright please view our takedown policy at https://edshare.gcu.ac.uk/id/eprint/5179 for details of how to contact us. 


\section{Heat recovery from mineworkings: opportunities in the Glasgow area}

\section{Author 1}

- Nicholas Hytiris, BSc, MSc, PhD in Geotechnics / Civil Engineering

- School of Engineering \& Built Environment, Glasgow Caledonian University, Glasgow, UK.

\section{Author 2}

- Rohinton Emmanuel, BSc Built Environment, MSc Architecture, PhD Architecture

- School of Engineering \& Built Environment, Glasgow Caledonian University, Glasgow, UK.

\section{Author 3}

- Bjorn Aaen, BSc

- School of Engineering \& Built Environment, Glasgow Caledonian University, Glasgow, UK.

\section{Author 4}

- Emma Suzanne Church, BSc, MSc, PhD student

- School of Engineering \& Built Environment, Glasgow Caledonian University, Glasgow, UK.

\section{Author 5}

- Diarmand Seumas Campbell, BSc, MSc, PhD

- British Geological Survey, Chief Geologist of Scotland, Edinburgh, UK

\section{Author 6}

- Konstantinos Ninikas, BSc Mechanical Engineering, associate researcher

- School of Engineering \& Built Environment, Glasgow Caledonian University, Glasgow, UK.

\section{Author 7}

- Andrew Robertson, BSc

- MSc student, Heriot Watt University, Edinburgh, UK 
Corresponding author: Nicholas Hytiris, N.Hytiris@gcu.ac.uk, Tel: 0044141273 159370, Glasgow Caledonian University, School of Engineering \& Built Environment, 70 Cowcaddens Road, G4 OAB, Glasgow, Scotland, UK.

\begin{abstract}
Glasgow is one of many locations within the United Kingdom once dotted with a number thriving coal mines. Before the suitability of the water stored in mines can be determined for use in GSHP heating applications, it is essential to rule out any risk of contamination caused by exposure to this water.

This study examines water samples obtained from boreholes drilled directly above abandoned and flooded mine workings. It indicates that the chemistry of the water flooding the mines beneath Glasgow is suitable for use in ground source heat pump (GSHP) heating applications. The development of such systems in the future could help bring Glasgow forward in its ambition to become one of Europe's top ten sustainable cities by the year 2020, as well as helping to transform previously neglected and impoverished areas of the city, to areas full of potential by creating a number of jobs, homes and opportunities for the people living in this area.
\end{abstract}

\title{
Keywords:
}

Energy Geotechnics, Geoenvironment, Mining and Environmental Issues, Sustainable Development

\section{List of notation:}

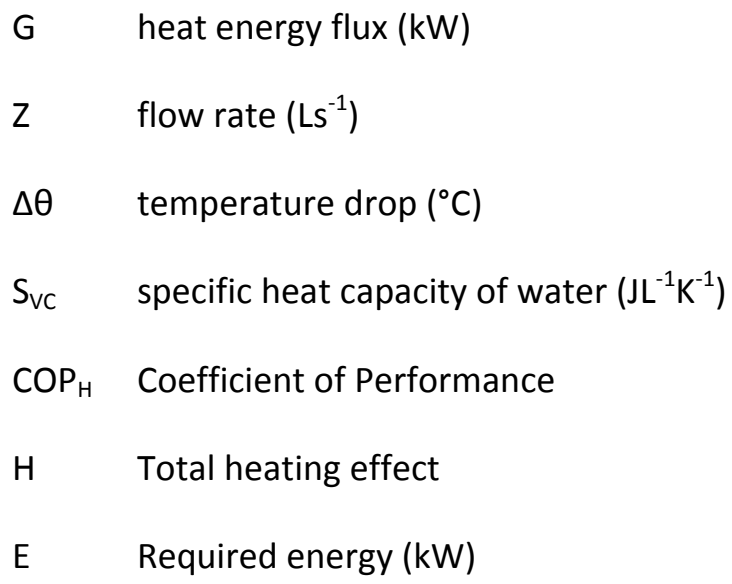

\section{Introduction}

In light of the legislative requirement for substantial reduction in carbon emission in the UK and in Scotland, there is an imperative to decarbonise the energy supply at a rapid pace. While Scotland is well on its way to meeting its commitment to generate $100 \%$ of its electricity from renewable sources by $2020^{1}$, it is arguable whether such progress could be made with respect to renewable heat especially at larger (district) scales ${ }^{2}$. One possibility in this regard is geothermal energy, the 
process by which heat is taken from the Earth itself. Examples of this can be seen in the cities of Wilhelmsberg, Hamburg ${ }^{3}$ and Gamla Stan, Stockholm ${ }^{4,5}$, where large scale exploitation of geothermal heat is already a reality. Glasgow and its greater suburban area is ideally situated above a series of shallow and deep coalmines systems - a legacy of the industrial revolution but have been left abandoned for many years. As a result water has filled the caverns and has been subjected to increased amounts of pressure and geothermal energy from the Earth, which could potentially be exploited as a renewable source of heat. However, several technical, legislative, economic and governance barriers remain.

The aim of the present paper is to explore the temperature and chemical profiles of water from abandoned mineworkings in and around Glasgow with a view to establishing its suitability as a potential source of renewable heat. The study is based on data collected over a period of 3 months on the physical properties of the water from mineworkings, such as temperature, pressure and water table depth as well as chemical composition of water including $\mathrm{pH}, \mathrm{Cadmium}$, Manganese, Zinc, etc.

\section{Background}

The process of extracting heat from geological sources (including water from mineworkings) utilises a Ground Source Heat Pump (GSHP) which could be used to heat homes and buildings or to heat road surfaces and pavements in order to avoid the potentially hazardous build-up of ice and snow. The amount of recoverable heat could be easily calculated using formula such as Equation $1^{6}$. Two key variables in determining the amount of recoverable heat are the rate of flow of water and its temperature difference.

$$
G=Z \times \Delta \theta \times S_{V C}
$$

A constraint on the potential use of this water is its chemical composition which might disrupt the heating process by requiring additional purification and/or limit the possibility of its direct use. As such information on the chemical composition of the minewater is equally important.

Mass spectroscopy is the most effective and efficient way to analyse the chemical compounds. This process allows the accurate and detailed chemical analysis of a sample to identify what make up the mass and in what volumes. Traditionally either adding or taking away electrons from an atom or molecule, a process known as ionization and measuring the changes in the sample can yield detailed knowledge of the elements that are present ${ }^{7}$. A method of mass spectroscopy that could be used to analyze mine water samples is known as Atomic Absorption Spectroscopy (AAS). When a particle is excited and jumps to a higher energy state, it emits photons relevant to the difference in energy between the two levels. By analyzing the wavelength emitted by a sample, a reasonably accurate estimate of the chemical compounds that make up the sample can be made. However, AAS is not as sensitive as Inductively Coupled Plasma Mass Spectrometry (ICP-MS) which has detection limits of around 1000 times more sensitive and has a more advanced approach to particle separation.

Table 1 shows the threshold values for various chemicals in drinking water as per European guidelines ${ }^{8}$. Although the purpose of bringing the minewater to the surface is not to use it for drinking purposes, the threshold values in Table 1 provide useful reference points to indicate whether chemicals present in it may have an adverse effect on processes that involve human interaction. 
Once the chemical analysis of the minewater has been conducted the results can be compared to these values to determine the nature of cleanness (or otherwise) of the water. Along with these chemicals, it is also necessary to determine the acidity/alkalinity ( $\mathrm{pH}$ value) of the water which might affect the heat exchange system.

\section{Methods and materials}

Temperature, water depth and chemical composition of water from mineworkings were monitored at two sites above known mineworkings in and around Glasgow over a twelve month period.

Site 1 - Newmains, Wishaw $\left(55^{\circ} 46^{\prime} 20.6^{\prime \prime} \mathrm{N} 4^{\circ} 21^{\prime} 13.1^{\prime \prime} \mathrm{W}\right)$ three separate boreholes of varying depths were drilled at this site and temperature and water samples were collected on a weekly basis (Figure 1 and 2) from each of them over a three month period between October and December 2013. Additionally, water table depths were also measured, but less frequently since it is unlikely to vary by a large amount. It is a well-known fact that the maximum ground water permeability often takes place months after the actual rainfall, and, at that particular point in 2013 most rain intensity was exhausted by the end of December 2013.

Site 2 - Leithland, Pollock ( $55^{\circ} 49^{\prime} 43.2^{\prime \prime} \mathrm{N} 4^{\circ} 21^{\prime} 13.1^{\prime \prime} \mathrm{W}$ ) owned by Glasgow City Council was only accessible under supervision of the relevant council department staff, due to health and safety concerns (Figure 3 ) as such data was collected only once at this site.

(Figure 1 here)

(Figure 2 here)

(Figure 3 here)

The following protocol was carried out at the New Mains site. On arrival at the site the equipment used to perform the procedure was taken to the first borehole, were the protective lid of the pipe was removed. A line of rope was attached and secured to the end of a bailer that was used to collect the water from the pipe. This is a hollow plastic tube that allows the water to fill it up when it comes into contact with the fluid. As it was lowered down the shaft the nozzle at its end is kept closed by gravity, however when it hits the water it opens, allowing the water to fill it up. After a reasonable amount of time has passed for the bailer to fill up, it was then pulled back up through the borehole; gravity in turn closes the nozzle so that the water is secured inside. When it reached the surface it was emptied into an insulated container (Thermos Flask). A digital thermometer with an external probe (Tiny Tag Plus2 TGP-4020) was then placed in the water to measure its temperature and the time of measurement was noted. The thermometer stored the temperature readings against the time it was taken, which was later used to determine the water temperature at the respective boreholes. The water temperature was measured for 3 to 4 minutes to get a stable reading.

Once this was done the lid was secured back in place over the borehole to tamper proof it, and the whole process was repeated for the other two boreholes. The background climate (temperature, atmospheric pressure and rainfall) during the measurement period was later obtained from a nearby (approx. $4 \mathrm{~km}$ from the site) publicly available Met Office weather station (see www.metoffice.gov.uk). 
The Leithland site presented different challenges since mine water was being pushed to the surface, and therefore did not require to be removed by means of a bailer. This site was accessed on 13 November 2013 to carry out water temperature measurement and to collect a sample of water for chemical analysis.

\section{Results}

Figure 4 shows the ambient temperature variations during the measurement period which indicates a substantial variation in background weather.

(Figure 4 here)

The highest recorded value was $10^{\circ} \mathrm{C}$ on the 10 December and the lowest being $-1^{\circ} \mathrm{C}$ on the 19 November, with varying temperatures in-between. This variance in values was expected and was in line with typical conditions during late autumn / early winter in Glasgow.

Figure 5 shows the temperature variations in the three boreholes at the New Mains site. It is clear from the above the water temperature was very stable at all boreholes.

(Figure 5 here)

During two visits to the site, the water table depth was measured by the use of a piezometer. The depths from the surface were as follows:

(Table 2 here)

Table 3 shows the temperature readings from two boreholes at the Leithland site.

(Table 3 here)

R-4 showed an average value of $9.36^{\circ} \mathrm{C}$, not dissimilar to that of what was found the Newmains site; however R-3 yielded a high average value of $11.51^{\circ} \mathrm{C}$.

\section{Analysis}

To begin with, the background weather during measurements at the Newmains site showed a wide variation. From week to week there were differences in values of ambient temperatures, pressure and rainfall (not shown) which was typical of expected conditions during that time of the year. However there was not much variation between water temperature readings during the measurement period nor between the boreholes themselves. The average temperature for each borehole overall were $9.53^{\circ} \mathrm{C}, 9.59^{\circ} \mathrm{C}$ and $9.46^{\circ} \mathrm{C}$ for $\mathrm{R}-34, \mathrm{R}-36$ and $\mathrm{R}-40$ respectively. The highest recorded sample temperature was $9.93^{\circ} \mathrm{C}$ from borehole R-36 on the $22^{\text {nd }}$ October, and the lowest was $9.19^{\circ} \mathrm{C}$ from borehole R-40 on the $19^{\text {th }}$ of November, i.e. a difference of only $0.74^{\circ} \mathrm{C}$ between the two extremes. Overall the data shows that the water is being kept at a relatively constant state under the ground, and that no changes in the weather or the surface conditions have an effect on the physical properties of the water. No matter what weather patterns present themselves, as long as the water table remains at a constant height to keep the mines submerged, the mines in Glasgow should produce water at temperature between the $9^{\circ} \mathrm{C}$ and the $10^{\circ} \mathrm{C}$.

With regards to the Leithland data, borehole R-4 produced a sample that was comparable to the Newmains site if not slightly less than the three average temperatures were found there. Borehole $\mathrm{R}-3$, on the other hand, gave a significantly higher value $\left(11.51^{\circ} \mathrm{C}\right)$, however, while the water was 
rising to the surface it was significantly faster than $\mathrm{R}-4$. This could be due to geomorphologic differences in a rock mass and permeability characteristics. A further possible explanation may have been that the borehole R-3 had a smaller cross-section than R-4, thus increasing the speed of the water as it comes to the surface, which would lead to a higher temperature value.

(Figure 6 here)

\section{Potential power output}

The measured data from the two sites and using equation 1 (Section 2) give a better understanding of the power output that could be utilized from the mine water. Taking the highest average value from borehole R-36, at the Newmains site $\left(9.59^{\circ} \mathrm{C}\right)$ this will probably produce a temperature drop value $(\Delta \theta)$ of around $3^{\circ} \mathrm{C}$. Assuming also a reasonable flow rate of approximately 1 litre per second $(\mathrm{Z})$, and the specific heat of water $\left(\mathrm{S}_{\mathrm{VC}}=4180 \mathrm{JL}^{-1} \mathrm{~K}^{-1}\right)$, the total heat energy is as follows:

$$
\mathrm{G}=1 \mathrm{~L}^{-1} \times 3^{\circ} \mathrm{C} \times 4180 \mathrm{JL}^{-1} \mathrm{~K}^{-1}=12540 \mathrm{Js}^{-1} \text { or } 12.54 \mathrm{~kW}
$$

Assuming a Coefficient of Performance $\left(\mathrm{COP}_{H}\right)$ value (which can vary between 3 and 5 ) of 4 and using equation $2^{6}$ the total likely recoverable heat from Glasgow's minwater is:

$$
G=H \times\left(1-\frac{1}{\operatorname{COP}_{H}}\right) \quad \text { Eq. } 2
$$

$12.54=\mathrm{H} \times(1-1 / 4) \rightarrow \mathrm{H}=12.54 \times 4 / 3=16.72 \mathrm{~kW}$

Which leaves an E value of $4.18 \mathrm{~kW}$ as equation $3^{6}$ states that the total heating effect $(\mathrm{H})$ :

$$
H=G+E
$$

$E=H-G=16.72 \mathrm{~kW}-12.54 \mathrm{~kW}=4.18 \mathrm{~kW}$

This means that in order to achieve an effective heating effect of $16.72 \mathrm{~kW}$, the pump would require a constant power supply of $4.18 \mathrm{~kW}$.

Following the same process of calculations but for the Leithland site, which would realistically mean increasing the $(\Delta \theta)$ value to $4^{\circ} \mathrm{C}$, provides an end value of $\mathrm{G}=16.72 \mathrm{~kW}$ and $\mathrm{H}=22.29 \mathrm{~kW}$, leaving a power requirement of $\mathrm{E}=5.57 \mathrm{~kW}$. However this could potentially peak with a $\Delta \theta=5^{\circ} \mathrm{C}$ and an upper $\mathrm{COP}_{\mathrm{H}}$ value $=5$ at a high rate for ground source heat of $\mathrm{G}=20.9 \mathrm{~kW}$ and a total heating effect of $\mathrm{H}=34.8 \mathrm{~kW}$, provided the pump has a power supply of $\mathrm{E}=13.9 \mathrm{~kW}$.

$\mathrm{OFGEM}^{9,}$ and $\mathrm{DECC}^{10}$ reported that a typical UK household consumes per annum approximately $16,000 \mathrm{kWh}$ for heating purposes. Assuming that the heating stays on for 8 hours per day for a period of 8 months this is translated into approximately 1900 heating operational hours which means $8.5 \mathrm{~kW} / \mathrm{h}$ energy input.

Thus the above heat from minewater could power up 2.5 households at a flow rate of 1 litre per second.

\section{Water quality}

From the samples collected at the Newmains site, laboratory work yielded only trace amounts of contaminates such as iron. However the Leithland site produced an interesting set of results in that it too had trace amounts of contamination of various substances, but also excessive volume of iron. 
The chemical analysis of the water samples from the Newmains and Leithland sites are shown in Tables 4 and 5 respectively.

(Table 4 here)

(Table 5 here)

By comparing both sets of results, it is apparent that there are major discrepancies between the concentrations of the substances tested for each analysis.

In theory, AAS and ICP-MS methods should provide correlating results from analysis of the same sample. However when testing an environmental sample, such as the water samples taken from mineworkings, all chemical, physio-chemical and microbiological properties of the sample must be characterized prior to analysis in order to avoid possible interferences. The results obtained from AAS analysis may be considered less reliable than the ICP-MS results due to the increased possibility of substance interference routing from a less technically advanced method of atomisation. As such the reason for the discrepancy between the two samples may be partly justified by the fact that ICPMS process was able to transform more atoms of the substances into their ionic states.

Any extraction of mine water from the Leithland site would require extensive treatment for iron contamination. Comparing the evident water quality in Table 4 from the Newmains site, to that of Table 5 from Leithland, it is clear that there is some difference in the water quality between the two locations.

\section{Implications and Conclusions}

The ambitious renewable energy - especially renewable heat - targets of the Scottish Govt. could only be met by the large scale use of new technology and heat from mineworkings might provide an opportunity in the case of Glasgow. Our work has shown that relatively small quantities of mine water at shallow depths (at a depth below the water table) provide adequate heat. It has also been shown that not only is this water being kept warm by additional amounts of pressure, but also changes in outdoor weather conditions has no effect on the physical properties of the water. As such it can be seen that the water is being kept warm solely by the mine systems.

The emphasis of this work has been directed towards whether or not it is feasible and sustainable to harvest water from mine systems for the purposes of heating, by using ground source heat pumps.

What was found at the Newmains and Leithland sites was a clear indication that the water in the mine systems was indeed being kept at a temperature sufficient enough to be used for the purposes of heating. From what was recorded on site each borehole yielded an average temperature of $9.36^{\circ} \mathrm{C}$ $-11.51^{\circ} \mathrm{C}$, a variance of $22.97 \%$ at the Leithland site, and a $1.37 \%$ variance at the Newmains site. Although it has to be pointed out that there was a $20 \%$ difference in the highest temperature between the two sites. With regards to the water table depths at the Newmains site, there was a slight variance of $1 \%$ in borehole R-34's height, while R-36 stayed the same. However there was a recorded difference of $20 \%$ between the heights recorded for bore hole R-40.

With the values that were recorded at both sites, and by using the relevant formulas, the potential power output was calculated. In a worst-case scenario, there is a potential to produce a total heating effect of $16.72 \mathrm{~kW}$, and $22.29 \mathrm{~kW}$ in a best-case scenario. That's a total variance between these two extremes of $33.3 \%$. 
From the chemical analysis tests that were undertaken the Newmains site yielded results that showed trace elements of contaminants, but none with high enough concentrations that would merit concern. However the Leithland site was shown to have 64.4 times higher concentration of iron than a lethal dosage for a human being, and 8 times higher concentration of manganese than a recommended ingested volume.

The present work thus improves our understanding of the heat potential available in Glasgow's abandoned mines. There may however be water quality challenges that may need to be overcome before heat exploitation becomes a reality. We have reason to believe that the Leithland water samples are more representative than the others because they were taken directly from the mineworkings.

\section{Acknowledgements}

The authors wish to thank Mrs. Claire Robertson final year dissertation student as well as Mr. Donald Linn Chief Geotechnical Engineer - Glasgow City Council for their contribution to this project.

\section{References}

1. Scottish Government 29 March, 2012, Scotland beats 2011 green energy target. See: http://www.scotland.gov.uk/News/Releases/2012/03/geenenergytargets29032012 Accessed 31.03.2015

2. Baker K, Emmanuel R, Phillipson M. 2011. Final Report: Support for RPP2 Housing Futures, Reference: CXC1109-01. Report submitted to Scotland and Northern Ireland Forum For Environmental Research (SNIFFER) on behalf of ClimateXChange. See: http://www.gov.scot/resource/0038/00389071.pdf Accessed 31.03.2015

3. Wilhelmsburg Central Integrated Energy Network, 2014. See: http://www.ibahamburg.de/fileadmin/Slideshows_post2013/02_Wissen/01_Whitepaper /140719_WHI_EVWBM_english.pdf Accessed 11/03/2014.

4. Bit tooth energy, Stockholm, district heating, 2009. See: http://bittooth.blogspot.co.uk/2009/03/stockholm-district-heating-and-warren.html Accessed 11/03/2014.

5. Stockholm. European Green Capital 2010. See: http://ec.europa.eu/environment/europeangreencapital/wp-content/uploads/ 2013/02/ brochure_stockholm_greencapital_2010.pdf Accessed 11/03/2014.

6. Banks, D. An introduction to thermogeology ground source heating and cooling, WileyBlackwell, Second Edition, 2009. Pages $(93,99)$

7. Metcalfe, E. Atomic absorption and emission spectroscopy, First Edition, Controller of Her Majesty's Office, Great Britain, 1987

8. European Union. 1998, Official journal of the European community's collective directive 98/83/EC quality of water intended for human consumption. Council of European Union

9. OFGEM, 2011. Typical domestic energy consumption figures See: https://www.ofgem.gov.uk/ofgem-publications/76112/domestic-energy-consump-fig-fs.pdf, 2011. Accessed 31.03.2015

10. DECC, 2015. Energy consumption in the UK (2014) See: https://www.gov.uk/government/uploads/system/uploads/attachment_data/file/338662/e cuk_chapter_3_domestic_factsheet.pdf. Page 7. Accessed 25.03.2015 
Figure captions

Table 1. Health legislative thresholds for different chemicals in drinking water

Figure $1 . \quad$ Site 1: New Mains, Wishaw

Figure 2. Detail view of a borehole at Site 1

Figure $3 . \quad$ Site 1: Leithland

Figure 4. Background temperature at the MET office station during the measurement period

Figure $5 . \quad$ Minewater temperature at the New Mains site

Table 2. Water table depths at the New Mains site

Table 3. Water table depths at the Leithland site

Figure 6. All five average temperature results from boreholes

Table 4. Water quality at the New Mains site, using AAS

Table 5. Water quality at the Leithland site, using ICP-MS 
Table 1

\begin{tabular}{|c|c|c|}
\hline Chemical & Acceptable Volume (mg/l) & Lethal human dosage \\
\hline Cadmium & 0.005 & $20-30 \mathrm{mg} / \mathrm{l}$ \\
\hline Chromium & 0.05 & $1-2 \mathrm{~g}$ \\
\hline Copper & 2 & $10-20 \mathrm{~g}$ \\
\hline Iron & 0.2 & $200-250 \mathrm{mg} / \mathrm{l}$ \\
\hline Lead & 0.01 & $0.08 \mathrm{mg} / \mathrm{l}$ \\
\hline Manganese & 0.05 & $\mathrm{n} / \mathrm{a}$ \\
\hline Nickel & 0.02 & $n / a$ \\
\hline Sulphate & 2.5 & $\mathrm{n} / \mathrm{a}$ \\
\hline Zinc & $\mathrm{n} / \mathrm{a}$ & $\mathrm{n} / \mathrm{a}$ \\
\hline
\end{tabular}

Figure 1

Sampling Locales within Newmains Site
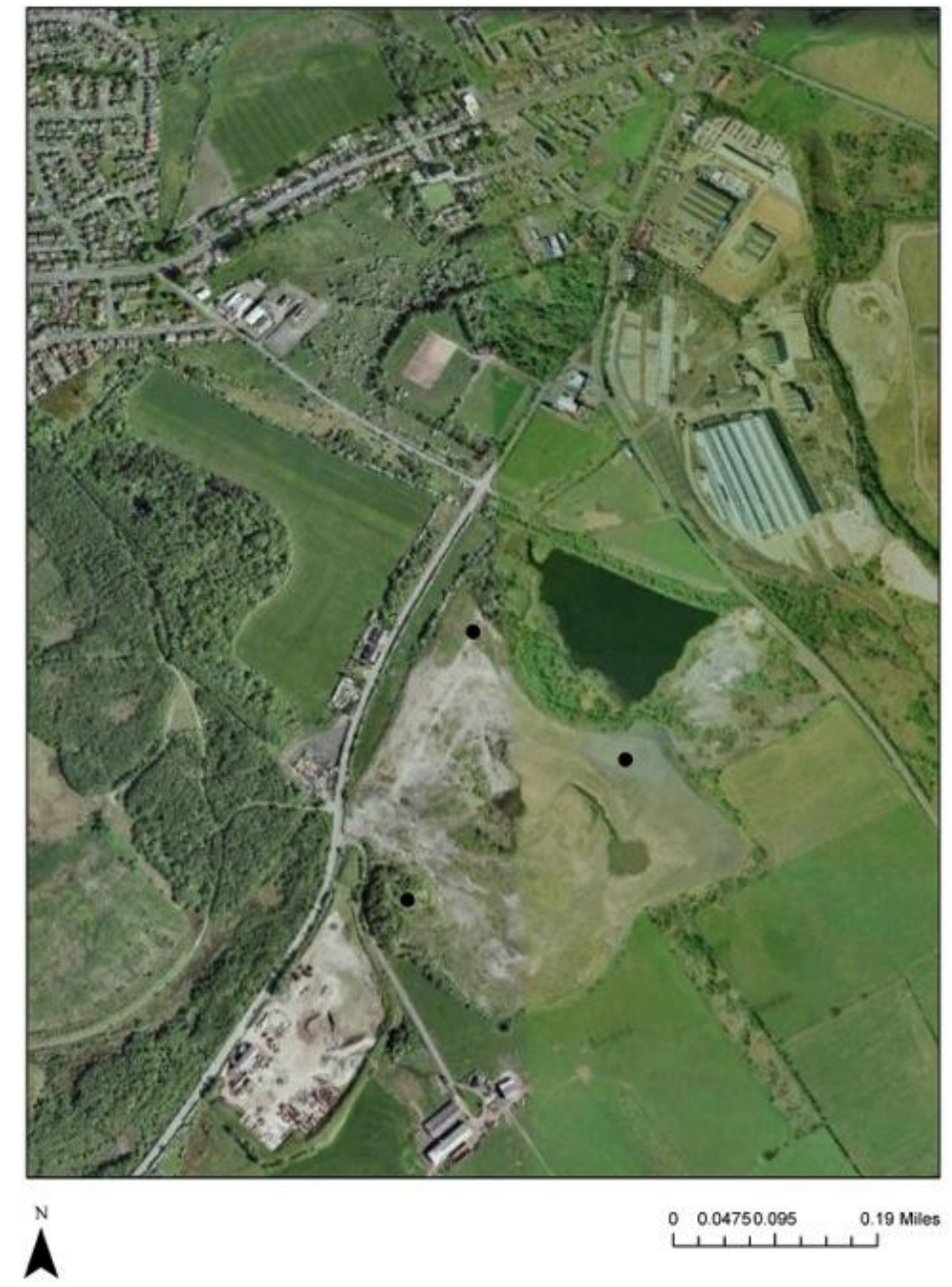

Figure 2 


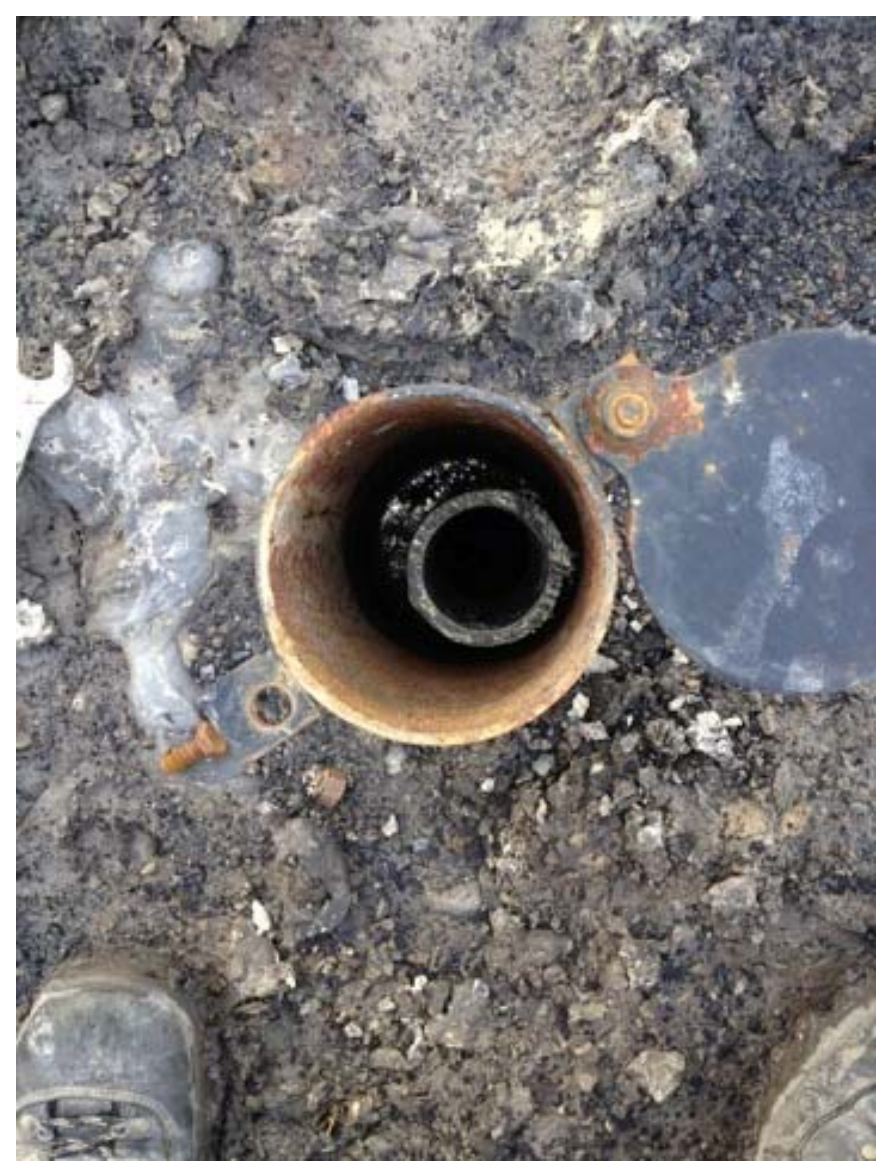

Figure 3

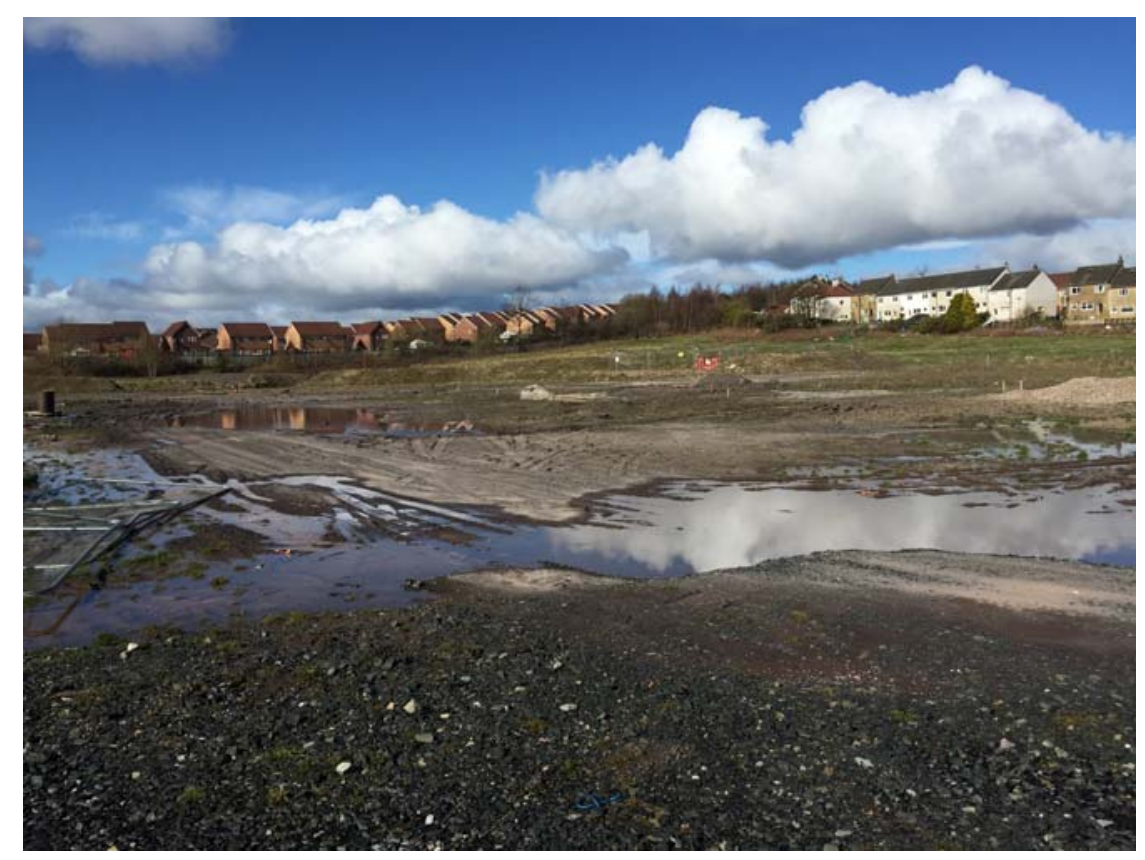

Figure 4 


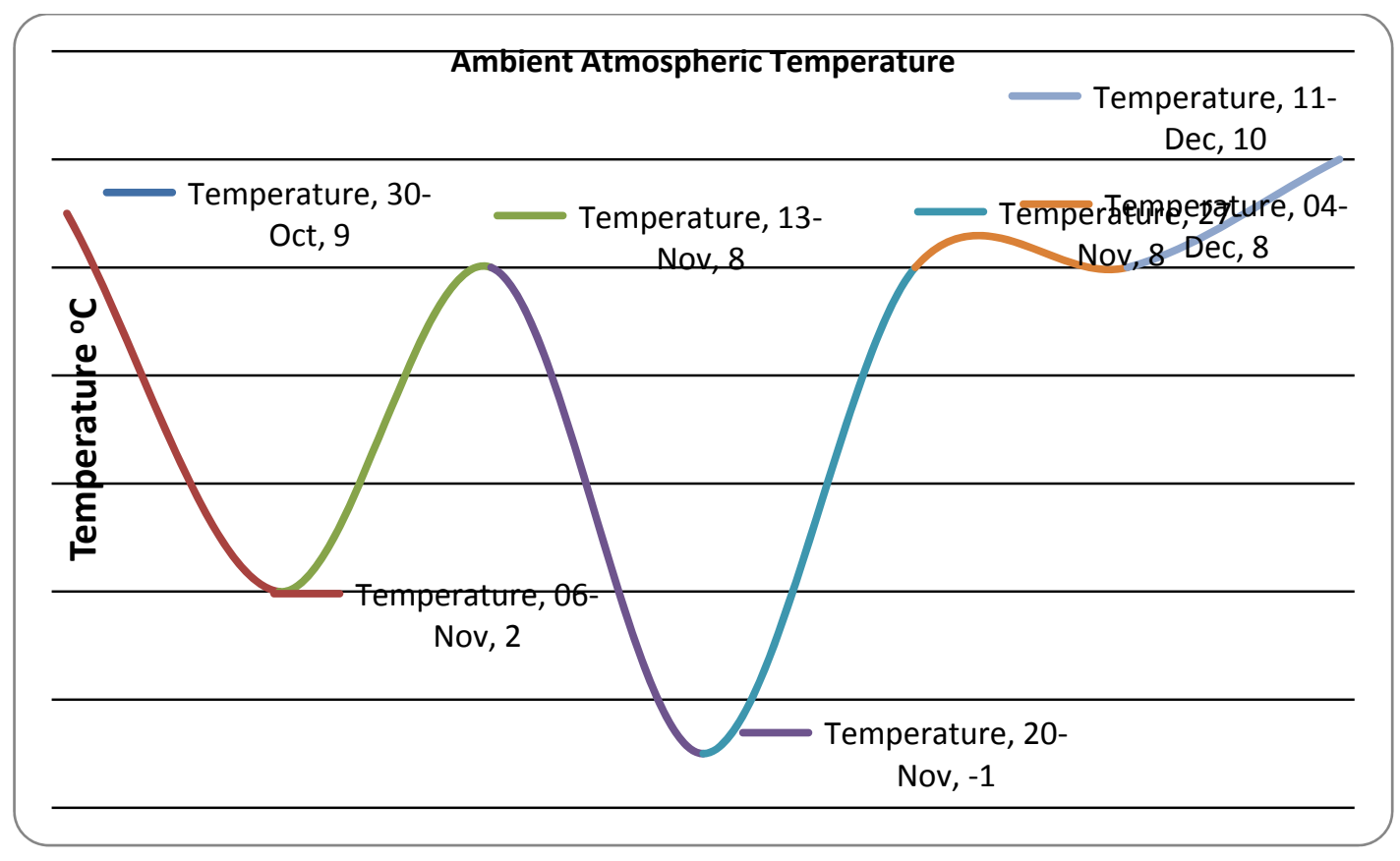

Figure 5

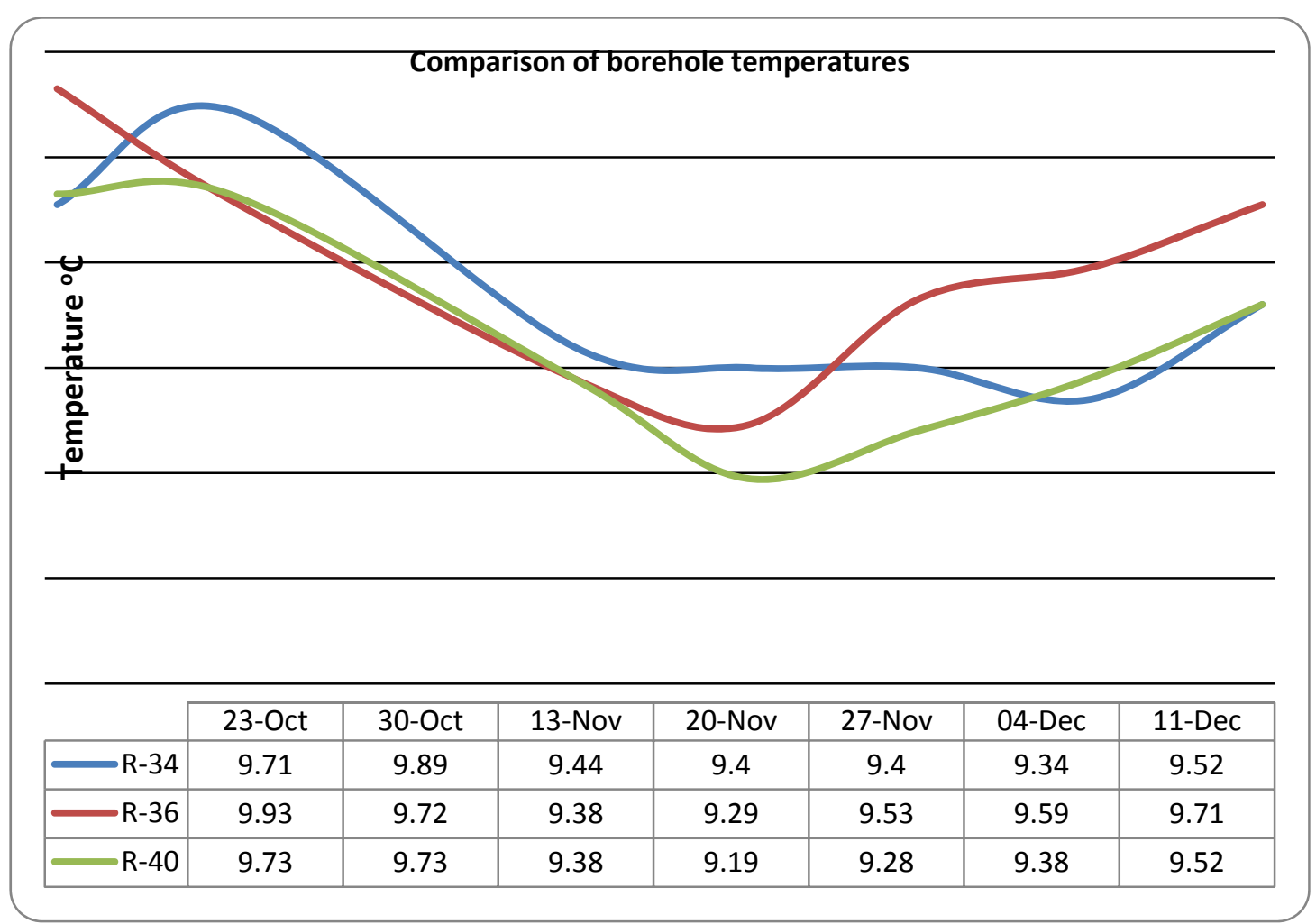


Table 2

\begin{tabular}{lll}
\hline Borehole & $26 / 11 / 2013$ & $10 / 12 / 2013$ \\
\hline R-34 & 19.5 m depth & 19.3 m depth \\
R-36 & 20 m depth & 20 m depth \\
R-40 & 17 m depth & 21 m depth \\
\hline
\end{tabular}

Table 3

\begin{tabular}{lll}
\hline Borehole & $\mathrm{R}-3$ & $\mathrm{R}-4$ \\
\hline Temperature $\left({ }^{\circ} \mathrm{C}\right)$ & $\mathbf{1 1 . 5 1}$ & $\mathbf{9 . 3 6}$ \\
\hline
\end{tabular}

Figure 6

Average temperatures of boreholes from both sites

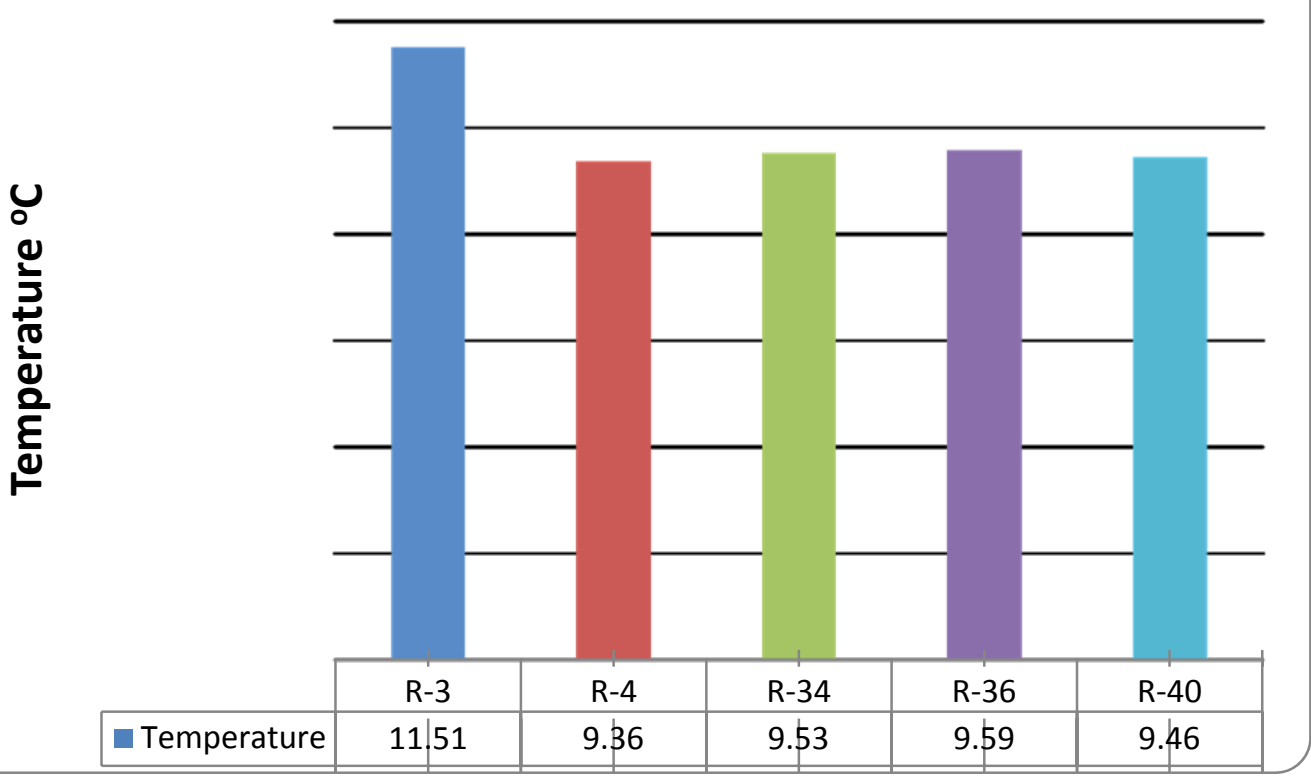

Table 4

\begin{tabular}{llll}
\hline Substance & $\begin{array}{l}\text { R-34 } \\
\text { Concentration } \\
(\mathrm{mg} / \mathrm{l})\end{array}$ & $\begin{array}{l}\text { R-36 } \\
\text { Concentration } \\
(\mathrm{mg} / \mathrm{l})\end{array}$ & $\begin{array}{l}\text { R-40 } \\
\text { Concentration } \\
(\mathrm{mg} / \mathrm{l})\end{array}$ \\
\hline $\mathrm{pH}$ & $\mathbf{6 . 7}$ & $\mathbf{6 . 8}$ & $\mathbf{6 . 5}$ \\
Cadmium & $\mathbf{0 . 0 3 6 0 3}$ & $\mathbf{0 . 0 3 9 3 3}$ & $\mathbf{0 . 5 2 9 3}$ \\
Chromium & Not detected & Not detected & Not detected \\
Copper & Not detected & Not detected & Not detected \\
Iron & Not detected & Not detected & Not detected \\
Manganese & $\mathbf{0 . 4 1 3 1}$ & $\mathbf{0 . 6 9 9 4}$ & $\mathbf{1 . 0 3 6}$ \\
Nickel & Not detected & Not detected & Not detected \\
Zinc & $\mathbf{0 . 0 5 9 8 9}$ & $\mathbf{0 . 0 7 5 6 5}$ & $\mathbf{0 . 1 0 3 4}$ \\
\hline
\end{tabular}


Table 5

\begin{tabular}{ll}
\hline Substance & Concentration $(\mathrm{mg} / \mathrm{l})$ \\
\hline $\mathrm{pH}$ & $\mathbf{6 . 8}$ \\
Sulphate & $\mathbf{1 2 5 0}$ \\
Cadmium & $<0.0002$ \\
Chromium & $\mathbf{0 . 0 0 1}$ \\
Copper & $<0.001$ \\
Iron & 16.1 \\
Lead & $<0.0005$ \\
Manganese & $\mathbf{0 . 3 8 1}$ \\
Nickel & $\mathbf{0 . 0 0 3 5}$ \\
Zinc & $<0.01$ \\
\hline
\end{tabular}

